
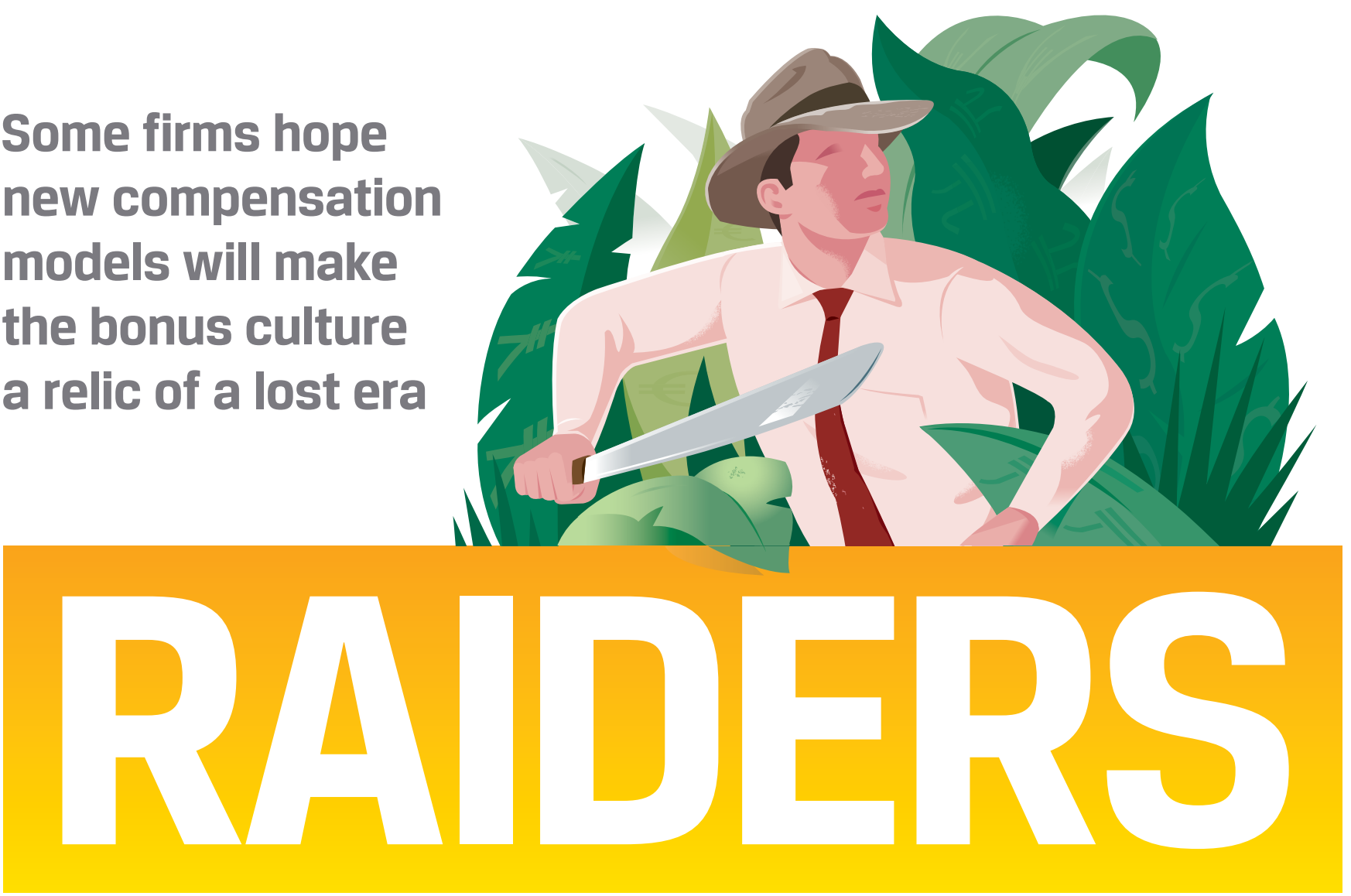

\title{
OF THE MISSED MARK
}

By Maha Khan Phillips

When a major firm makes fundamental changes to its compensation model, financial services professionals must wonder whether the move portends a larger trend. In April 2016, Woodford Investment Management, the \$14 billion UK asset management company set up by star manager Neil Woodford, announced that it was changing its staff remuneration structure. The firm ceased paying discretionary bonuses. Instead, all employees now receive a fixed salary.

"We've implemented a remuneration scheme that is fair and appropriate for Woodford employees and, ultimately, clients. Drawing on our experience of various bonus-led remuneration models, we concluded that bonuses are largely ineffective at influencing the right behaviours," said Craig Newman, CEO of the firm.

The key to the decision is the lack of a proven correlation between bonus and performance: "Many studies conclude that bonuses don't work as a motivator, as expectation is already built in," said Newman. "Behavioural studies also suggest that bonuses can lead to shortterm decision making and wrong behaviours."

The announcement comes at a time when asset managers face increasing scrutiny about what they pay their staff. According to Financial Times fund management (FTfm) analysis, the chief executives of the world's largest asset management companies received bonuses that were on average 15 times larger than their salaries in the previous year. FTfm further analysed the executive pay at the 20 largest listed fund management companies in Europe and the United States, finding that the ratio of variable pay to fixed salary was far higher in asset management than in investment banking.

In fact, pay is falling at investment banks and rising at asset management firms, according to a February 2016 report by London-based think tank New Financial. The report, "Taking Stock on Pay," reveals that investment banks' average compensation cost per employee, a decent proxy for pay, fell by 25\% between 2007 and 2014 to approximately $\$ 295,000$ and was estimated to have fallen 
to $\$ 278,000$ in 2015 . In the six years before the Global Financial Crisis, pay represented $49 \%$ of investment banking revenues; in the six years after the Crisis, this proportion fell to $41 \%$. Bonus pools are shrinking in absolute and relative terms: A sample of six banks with comparable disclosure revealed that bonus pools shrank 31\% between 2010 and 2014 .

In contrast, asset management pay rose to $\$ 263,000$ in 2014. During the past decade, pay as a percentage of revenues has remained flat at about $35 \%$ and has been increasing in line with growth in assets under management. The latter trend also reflects an increase in asset prices since the Crisis, according to New Financial.

The firm does point out that investment banks have tens of thousands of staff and a long tail of support staff, whereas asset management firms employ only a few hundred or a few thousand staff, making it difficult to read too much into the comparison. But the trend is clear. Asset managers are getting paid more than they have in the past, and not everyone is happy about it.

\section{CALLS FOR TRANSPARENCY}

Critics say that asset managers now need to step up. "The first step needs to be more transparency," argues Camilla de Ste Croix, senior policy officer at ShareAction, a charity that campaigns for responsible investment. "We have been campaigning for institutional investors to have more visibility on all the fees and charges that they have been paying. It's difficult for there to be competitive pressure if you don't

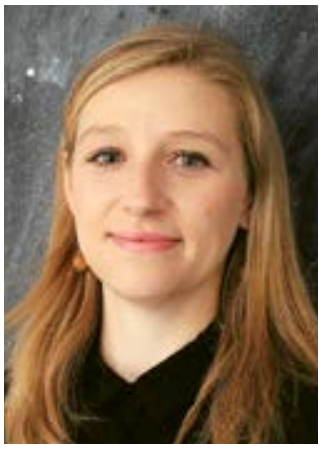

Camilla de Ste Croix know exactly what asset managers are being paid. It's not the quantum of pay but how the bonuses are structured and what kind[s] of behaviours are being incentivised."

Ste Croix believes that asset management has little incentive to engage with companies that have high levels of executive pay until they engage within their own companies. "The more interesting question is: How much are they acting as stewards of the capital and engag-

ing with the companies they are holding to account?" she says. Ste Croix suggests that managers have little appetite for engagement because they fear it might lead to scrutiny of pay within asset management itself.

The UK's Financial Conduct Authority (FCA), following an asset manager market study published last November, has made similar overtures. "In today's world of persistently low interest rates, it is vital that we do everything possible to enable people to accumulate and earn a return on their savings which can meet their lifetime needs," says Andrew Bailey, chief executive at the FCA, in a recent press release. "To achieve this, we need to ensure that competition in asset management works effectively to minimise the cost of investment. We want to see greater transparency so that investors can be clear about what they are paying and the impact charges have on their returns."

\section{THERE IS A SEPARATE QUESTION ABOUT THE APPROPRIATENESS OF THE MAGNITUDE OF PAY IN THE INDUSTRY, AND THAT'S A PRESSING QUESTION FOR FIRMS, BECAUSE WE ARE IN AN ERA OF LOW INTEREST RATES, AND IT'S DIFFICULT TO GENERATE HIGH RETURNS.}

\section{REGULATION}

In Europe, asset management, like the investment banking industry before it, is undergoing its own regulatory shakeup, and pay models are changing as a result. Under the remuneration requirements of Undertakings for the Collective Investment in Transferable Securities (UCITS) V, which took effect in January 2017, every UCITS manager will need to put in place remuneration policies that are consistent with and promote sound and effective risk management approaches. Managers will need to ensure that pay does not encourage any excessive risk taking that is not in line with the fund's risk parameters and does not affect a manager's ability to act in clients' best interests.

Certain UCITS managers will have to establish remuneration committees, and all managers will have to disclose information regarding their remuneration policies and pay practices. The regulation has been designed to work in tandem with the Alternative Investment Fund Managers Directive and also contains a number of requirements similar to those already in the Capital Requirements Directives-legislation implemented for the banking sector-with the notable exception of a bonus cap.

"The whole rationale behind imposing a cap on variable remuneration for bankers was a safety and soundness issue," explains Rhodri Preece, CFA, head of capital markets policy for the EMEA region at CFA Institute. "Asset management is an agency business. It doesn't pose the same systemic implications." Preece does agree, however, that pay structures should be analysed internally by institutions.

"There is a separate question about the appropriateness of the magnitude of pay in the industry, and that's a pressing question for firms, because we are in an era of low interest rates, and it's difficult to generate high returns," he says. "As a result, there is scrutiny around fees that fund managers are charging for their products, so it's only right that there is a greater scrutiny to the level of compensation that is paid. From an investor standpoint, you want a strong alignment of interests between the manager and the investor, and remuneration policies should be designed to deliver that alignment."

Under UCITS V, managers will also have to ensure that they have the option of not paying variable remuneration. They may pay guaranteed variable remuneration only in 
the first year following a new hire (and then only in exceptional circumstances). They will need to use both financial and non-financial criteria to assess performance and pay variable remuneration only if doing so is sustainable. Between $40 \%$ and $60 \%$ of variable remuneration must be deferred over a three- to five-year period, and at least $50 \%$ of the variable component needs to be in non-cash instruments if the UCITS accounts for more than $50 \%$ of the total portfolio under management.

The European Securities and Markets Authority, which published its Guidelines on Sound Remuneration Policies under the UCITS Directive and AIFMD in March 2016, says managers will have to look at the concept of proportionality. The provisions of the principle of proportionality will require institutions to consider remuneration policies "in a way and to the extent that it is appropriate to their size, internal organisation, and the nature, scope, and complexity of their activities." Accordingly, smaller and less complex firms that engage in simper activities will get a break, although all UCITS management companies are required to follow "all the principles governing remuneration policies."

\section{LOOKING AHEAD}

Some critics say that whether proportionality applies or not, UCITS V will have very little bite. "Instead of big bonuses, everyone's pay is going up, irrespective of whether they deliver or not," argues one consultant who wished to remain anonymous.

Others believe the regulation and the pressure that asset managers are under are slowly leading to a shift in remuneration practices. "Cost constraints are not going to dissipate, and this year has already seen significant volatility, which will have an impact on performance and pay," suggests Duncan Nicholls, a director at PricewaterhouseCoopers (PwC). "How do firms appropriately incentivise their people beyond financial remuneration? They will need to look at other ways of attracting and retaining talent through an increased focus on non-financial incentives, culture, diversity, and succession planning."

Nicholls also believes that global asset managers will have to rethink their approach as a result of the European regulations. "Global institutions are at a bit of a crossroads," he says. "The broad-brush approach to remuneration in a global organisation is not going to be fit for purpose for a number

\section{Compensation Cost Relative to Company Performance}

\begin{tabular}{|l|ccc|ccc|}
\hline & \multicolumn{2}{|c|}{$\begin{array}{c}\text { Total Compensation Spent As a } \\
\text { Percentage of Total Revenues }\end{array}$} & \multicolumn{2}{c|}{$\begin{array}{c}\text { Annual Bonus Costs As a } \\
\text { Percentage of Operating Profit }\end{array}$} \\
\hline Performance year & $\mathbf{2 0 1 4}$ & $\mathbf{2 0 1 3}$ & $\mathbf{2 0 1 2}$ & $\mathbf{2 0 1 4}$ & $\mathbf{2 0 1 3}$ & $\mathbf{2 0 1 2}$ \\
\hline Upper quartile & $47 \%$ & $44 \%$ & $42 \%$ & $34 \%$ & $35 \%$ & $27 \%$ \\
\hline Median & $39 \%$ & $39 \%$ & $37 \%$ & $25 \%$ & $26 \%$ & $20 \%$ \\
\hline Lower quartile & $34 \%$ & $32 \%$ & $30 \%$ & $15 \%$ & $17 \%$ & $10 \%$ \\
\hline
\end{tabular}

Source: PwC: Asset Management Remuneration ROI 2015

\section{Performance and Pay}

Asset management performance has come under a great deal of scrutiny relative to pay structures. A study by Cass Business School in London suggests that UK investors would be $1.44 \%$ better off each year if they switched to a passive manager. The study, which examined the monthly returns of 516 open-ended UK domestic equity mutual funds between 1998 and 2008 , revealed an average annual post-fee alpha of $-1.44 \%$.

Based on the findings, just $1 \%$ of fund managers qualify as "stars" who are able to generate superior performance after operating and trading costs. Once fees are taken out, nothing is left for investors, the study suggests.

"There are very few star managers out there. It takes a long time, from 10 to 15 years, to really realise that a star manager has skill," explains David Blake, director of the Pensions Institute at Cass Business School.

"The problem is that investors are just not able to advocate their sovereign rights as customers and force good value from the industry," he argues.

of organisations [that] will need to differentiate between their non-European employees and European employees."

In an April 2016 report titled "Rethinking Reward as Asset Management Moves Centre Stage," PwC argues that despite industry growth driving assets under management to an expected $\$ 102$ trillion by 2020 , pay will not increase at the same rate, and asset manager compensation as a percentage of revenue will fall from a high of $45 \%$ in 2010 to $35 \%$ by 2020 .

$\mathrm{PwC}$ further argues that half of the asset managers in its European universe have changed their remuneration strategies as a result of regulation to better align risk, performance, and pay. Investor preference for more collegial decision making, plus the emergence of passive and alternative strategies, means that the "star manager" culture used by so many institutions is being replaced by more team-based compensation structures.

Slightly more than half of firms already have some sort of incentive clawback in place, and investment professionals are deferring somewhere in the range of $25 \%-45 \%$ of their bonuses into a mixture of funds, shares, and cash. Four out of five firms have broad-based deferral plans in operation, and of these firms with deferral plans, $50 \%$ now operate deferral into funds.

PwC also predicts that by 2020 , "virtually all major territories will have introduced broad-based regulation to better align interests with the end customer." As the 
deleveraging of banks continues and asset management grows in importance, PwC expects that by 2020, "considerable information" about remuneration policies will be in the public domain, with most asset managers providing information for regulators and for investors. This will include total remuneration but also individual information about pay, such as the bonus amounts paid to key executives and employees.

\section{PAY MODELS}

Growing transparency will bring many benefits, but getting pay models right will be the challenge. Amin Rajan, CEO of CREATE-Research, points out some structural problems with current approaches. "After 2008, many fund managers introduced meritocratic practices," says Rajan. "These weren't just incentives linked to assets under management. So they moved in the right direction in terms of identifying the contribution of individual portfolio managers. However, when the portfolio manager wasn't doing well, he or

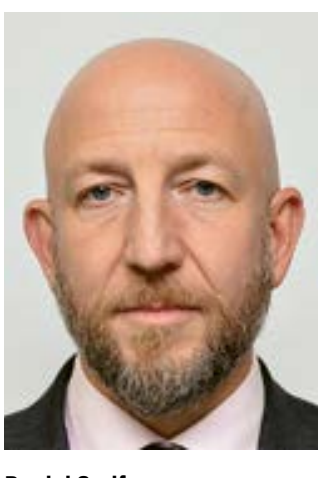
she was still being incentivised, for fear that they would leave, and consultants would put the fund on a watchlist," he says.

Rajan agrees that the culture is changing, though: "The old-style star culture, where bonus guzzlers were getting one or two million irrespective of what they produced, is not the kind of practice I see anymore."

Woodford Investment Management is not the only investment firm rethinking its approach. Daniel Godfrey, former CEO of the Investment Association in the United Kingdom, is seeking backers for his mutual investment company, The People's Trust. As of this article's publication, the company has received crowdfunding to the tune of more than $£ 100,000$ from over 2,200 backers. The investment trust, which will launch in early 2017, will be $100 \%$ owned by customers and will pay no bonuses to its executives. Instead, all employees will be paid a salary, partly in shares that must be held at least seven years so as to align the interests of executives with those of investors.

"If an investment manager is heavily incentivised by the amounts of assets under management, then there is a risk that the investment manager will spend a lot of time marketing and growing assets under management rather than managing the funds," argues Godfrey. "There's also a risk that the asset manager might not put their hand up and say that this particular strategy has reached its capacity and, if we keep growing the fund, the performance will be diluted."

He believes that the solution lies in fund managers being clear about their objectives and the criteria under which employees are paid: "Investment firms should publish the principles behind their incentive remuneration schemes. They should articulate to customers in plain English how the scheme works, discuss the timescales and the performance metrics, and so on, so the customer can measure that against what is being promised and decide for themselves whether there is a risk element."

\section{US AGAINST THEM}

Yariv Itah, principal and global practice leader at asset management consulting firm Casey Quirk, believes it is too simplistic for industry participants to be either in favour of high bonuses or against them. "There are two types of behaviours that hurt the investor, and asset managers need to find the balance between the two," he says. "If you underpay your investment team, you will lose that team, and that will hurt the investors who chose to invest in a product run by a certain team. If you pay the investment team in a way that incentivises them to take excess risk or not enough risk, then that also hurts the investor. So it's really important that how compensation is determined is aligned with what the investor is expecting to see."

Whether a firm offers variable pay should be based on the specifics of the product offering. "If a fund is expected to be very low risk or if this is something that follows the index closely, then it would mean you would want less variability in compensation and a more fixed component. However, if the investor has made a choice to invest in a highrisk, high-volatility product and the investment team is taking a fixed salary, then in a bad year not only are you seeing bad returns but you are also paying a high amount to your investment teams," Itah states.

Moreover, he points to what happened after the Global Financial Crisis. Asset management firms in Asia and Europe, which have a higher fixed component of compensation, were forced to cut staff across their institutions to reduce revenues. In the US, bonuses were cut, but fewer people lost their jobs, Itah argues.

"Investors benefitted from much more stability from the US firms during the down market, relative to firms which had only the fixed component of pay. When the markets picked up, US firms had the people to benefit from the inflows, whereas the firms that had just gone through major cutting of headcounts fell behind and were not able to compete for a year to 18 months until they could ramp up their businesses," he says.

\section{SYSTEMIC RISK}

But if regulatory requirements become more global, this may all be a moot point, particularly if market performance does not improve. According to Preece, the future is not set in stone: "The question about whether asset management is a systemic risk has not fully gone away. It's possible that legislators could revisit the issue and consider again the appropriateness of remuneration rules for asset management."

Maha Khan Phillips is a financial writer in London and author of the novels The Curse of Mohenjodaro and Beautiful from This Angle. 